\title{
Mechanisms and experimental and epidemiological evidence relating dietary fibre (non-starch polysaccharides) and starch to protection against large bowel cancer
}

\author{
BY SHEILA A. BINGHAM \\ $M R C$ Dunn Clinical Nutrition Centre, 100 Tennis Court Road, Cambridge CB2 1QL
}

In the UK all age incidence rates for large bowel cancer are second only to lung cancer in men, and breast cancer in women. Rates increase with age, from twelve cases per 100000 in men aged $40-45$ years, rising to 110 at age $60-65$ years, and to 419 at age 80-85 years in England and Wales. Age-standardized rates are even higher in areas such as Australia, USA, New Zealand and parts of Europe such as North Italy, Denmark and Germany. Low rates are seen in areas such as parts of South America, rural Africa, China, India and Kuwait. In Japan, colon cancer incidence has at least doubled since 1960 and Fig. 1 shows that rates for colo-rectal cancer continuously recorded by the Miyagi Cancer Registry are fast approaching those recorded by the Birmingham registry in Britain (Muir et al. 1987).

Migrant studies have suggested that these international differences are largely due to environmental factors, although within any one population, genetic factors will affect individual susceptibility to the development of cancer. A mutation common to the same gene on chromosome 5 has been involved in both the rare genetically inherited disease familial adenomatous polyposis, which markedly increases individual risk of colo-rectal cancer, and the 'sporadic' form of colo-rectal cancer which results in somatic mutation

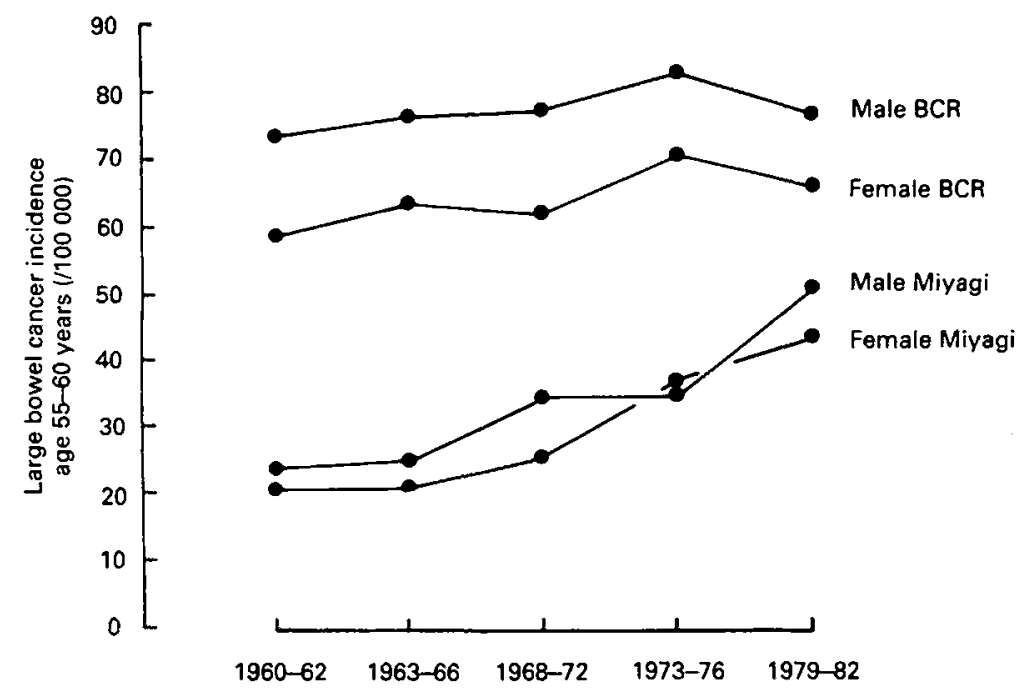

Fig. 1. Age-specific colon and rectal cancer incidence 1960-1982; England, Birmingham Cancer Registry (BCR); Japan, Miyagi Cancer Registry (Muir et al. 1987). 
and is presumed to be subject to environmental influences (Solomon et al. 1987). Other allelic deletions are also implicated in sporadic cancer, for example, on chromosome 17 (Baker et al. 1989).

Large bowel cancer incidence rates also vary amongst different groups within any one population, rates for vegetarian Seventh Day Adventists, for example, being much lower than those of the general USA population (Phillips \& Snowdon, 1983). Higginson \& Oettle (1960) were amongst the first to document differences in colo-rectal cancer incidence amongst different groups in South Africa, and to attribute the low rates in the Bantu to the fact that in the Bantu a large amount of roughage is consumed and constipation in the Western sense is rare'. This suggestion, however, only received widespread attention following the classification of large bowel cancer with a number of other large bowel disorders common in Western societies whose aetiology was attributed to lack of dietary fibre by Trowell, Burkitt and co-workers. Burkitt (1969) suggested a mechanism for the protective action of dietary fibre in stating that 'with regard to bowel tumours . . . with the Western diet, the greatly delayed transit time (most of the delay occurring in the distal colon), together with the concentration associated with diminished stool bulk, might enhance the action of any carcinogen by the multiple of these factors'.

Since that time, the 'fibre hypothesis' has attracted much research into the definition, analysis, physiology and epidemiology of dietary fibre in relation to disease. The existing evidence regarding the possible protective effect of dietary fibre in colo-rectal cancer will first be reviewed, followed by a discussion of the mechanisms whereby fibre might be involved.

\section{FIBRE SUPPLEMENTS AND CHEMICALLY INITIATED CARCINOGENESIS}

In animal models of colo-rectal cancer, lesions are induced using the carcinogens 1,2dimethylhydrazine (DMH), azoxymethane (AOM), and 3,2-dimethyl-4-aminobiphenyl (DMAB) which require microsomal activation. The direct-acting carcinogen methyl nitrosourea (MNU) may also be used.

The effect of purified sources of dietary fibre on chemically initiated colo-rectal cancer has been investigated in a large number of studies over the past decade. In these, the numbers of tumours induced by the administered carcinogen whilst the animals are fed on 'control' diets are compared with those found with fibre supplements. Although at first sight these types of experiments are easily standardized, comparisons between different studies are difficult due to differences in age, sex, strain and type of animal used, the chemical carcinogen used and its route of administration, the timing of carcinogen dosage (whether before or during fibre supplementation) and the level of dosage. These animal models are highly susceptible to nutritional factors such as the level of fat and energy in the control and experimental diets, and the type of fat used. Both increased levels of fat and energy are promoters of colon carcinogenesis, as are the $\omega 6$ polyunsaturated fatty acids (Ip, 1978). Further experimental variables are the level of fibre fed in the experimental diet and the level of fibre in the control diet, some studies having been carried out with chow as the control, and others a 'fibre-free' diet.

The overall findings of experimental studies were collated by the Federation of American Societies for Experimental Biology (FASEB) in 1987 (Pilch, 1987). Table 1 shows a summary of these for wheat bran, cellulose and pectin. In general, bran appears to have a consistently protective effect against chemical carcinogenesis. Of seventeen 
Table 1. Effect of fibre on protection against chemical carcinogens (Pilch, 1987)

\begin{tabular}{lcccc}
\hline $\begin{array}{l}\text { Type of } \\
\text { fibre }\end{array}$ & $\begin{array}{c}\text { No. of } \\
\text { studies }\end{array}$ & $\begin{array}{c}\text { Fibre } \\
\text { protective }\end{array}$ & $\begin{array}{c}\text { Fibre no } \\
\text { effect }\end{array}$ & $\begin{array}{c}\text { Fibre } \\
\text { enhancing }\end{array}$ \\
\hline Wheat bran & 17 & 13 & 3 & 1 \\
Cellulose & 9 & 6 & 3 & 0 \\
Pectin & 7 & 1 & 3 & 3 \\
\hline
\end{tabular}

studies, bran decreased the number of tumours in thirteen studies, and increased the number of tumours compared with control levels in only one study. Cellulose also appears protective in six of nine studies, with no significant difference in three. In three of seven studies, pectin apparently enhanced carcinogenesis, possibly due to the variety of experimental variables in these studies. Other brans from rice, soya beans, maize and oats have only been studied in a few experiments using variable protocols. No consensus was possible for the gums, guar gum and carrageenan (Pilch, 1987).

\section{EPIDEMIOLOGY OF DIETARY FIBRE INTAKE AND COLO-RECTAL CANCER}

Much of the evidence relating risk of large bowel cancer to lack of dietary fibre was based on the epidemiological observations of Burkitt and co-workers in Africa. Since that time, however, extensive epidemiological studies have been undertaken.

Correlation studies. A number of investigators have made international comparisons between colo-rectal cancer incidence or mortality rates with estimates of national average consumption of dietary fibre. McKeown-Eyssen \& Bright-See (1985) for example, correlated mortality rates for colon cancer in thirty-eight countries with estimated dietary fibre intakes calculated from Food and Agriculture Organization food balance sheets. Estimated dietary fibre intakes were higher in countries at low risk for colon cancer, with correlation coefficients relating total dietary fibre and cereal dietary fibre consumption to colon cancer death rates -0.66 and -0.72 . However, the strongest association between colo-rectal cancer and large bowel cancer epidemiologically is with meat (Amstrong \& Doll, 1975), and animal protein intake and cereal consumption are inversely related world-wide (Perisse et al. 1969). Hence, these relationships are substantially reduced on partial correlation analysis controlling for meat $(r-0.36)$ and fat $(r-0 \cdot 18$; McKeown-Eyssen \& Bright-See, 1985).

Population studies do not, therefore, suggest that there is a clear association between fibre intake and large bowel cancer. Other anomalies have also been reported. Age-standardized colo-rectal cancer rates of the Maoris in New Zealand are approximately half those of New Zealand whites, and yet intakes of dietary fibre are virtually the same (Smith et al. 1985). In South Africa, different racial groups are also at very different risks of large bowel cancer, yet recent reports suggest that fibre intakes in these groups are also very similar (Walker et al. 1986). The marked increase in large bowel cancer in Japan over the past 30 years (Fig. 1) has not been associated with changes in intakes of dietary fibre (Kuratsune et al. 1986). However, other items of the Japanese diet have changed substantially, and since 1950 there has been at least a threefold increase in fat consumption, a ninefold increase in meat consumption, and rice consumption has fallen by one-third (Minowa et al. 1983). 


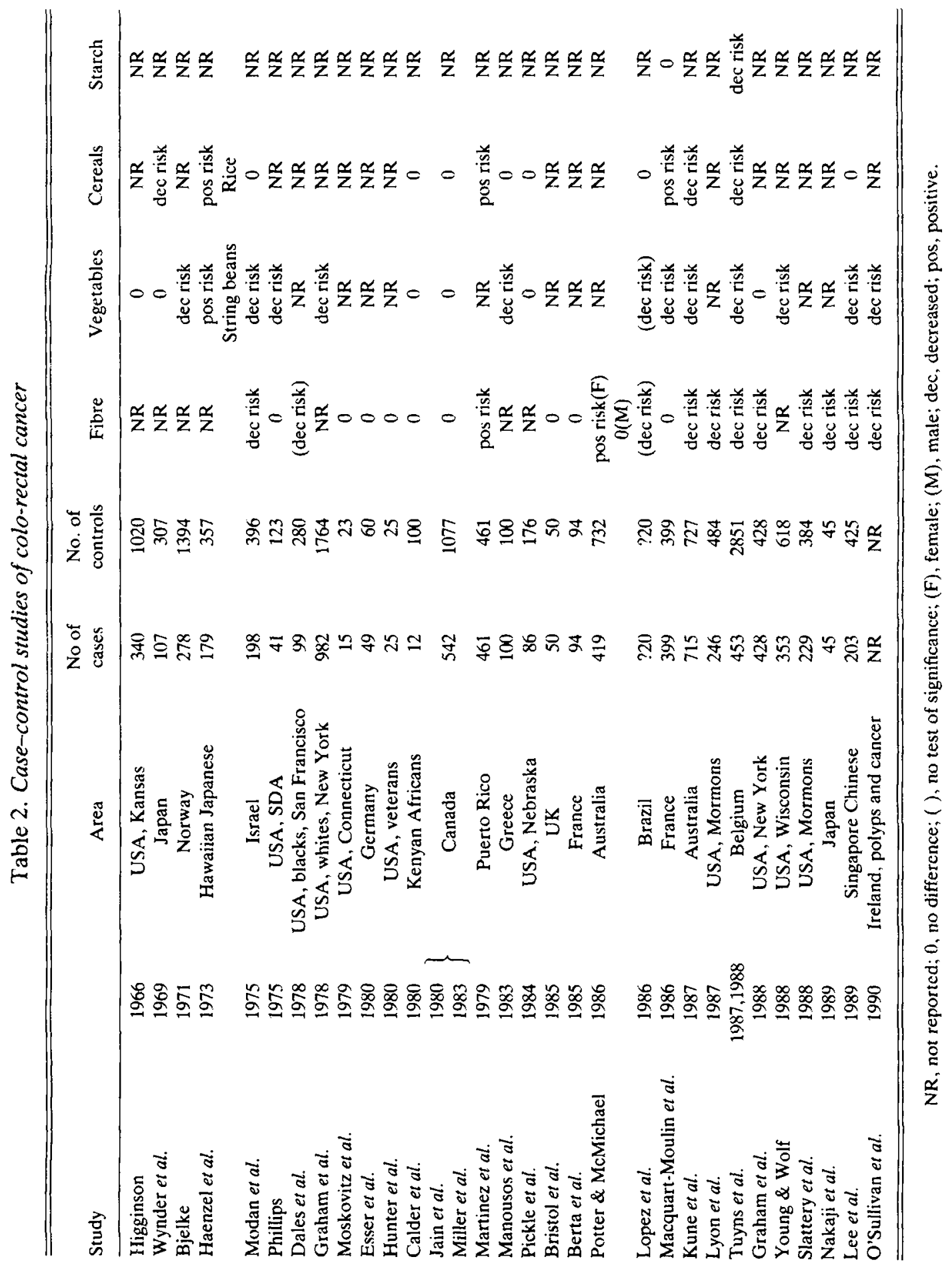


Table 3. Case-control studies of dietary fibre (thirty studies 1969-89)

\begin{tabular}{lcccc}
\hline & $\begin{array}{c}\text { No. of } \\
\text { studies }\end{array}$ & $\begin{array}{c}\text { Reduced } \\
\text { risk }\end{array}$ & $\begin{array}{c}\text { Enhanced } \\
\text { risk }\end{array}$ & No effect \\
\hline & 22 & 11 & 2 & 9 \\
& Fibre & 12 & 1 & 6 \\
Vegetables & 19 & 3 & 3 & 7 \\
Cereals & 13 & 1 & 0 & 1 \\
\hline
\end{tabular}

Case-control studies. In epidemiology, case-control studies offer major advantages over population studies because individual exposure to a dietary variable can be related to individual outcome. The most common type of study is the case-control, whereby individuals with a particular cancer are studied after diagnosis and the results compared with those for individuals who are healthy.

The results of thirty case-control studies carried out in Europe, Australasia, North and South America, and Africa, over the past 20 years are shown in Table 2. Values for 'fibre' were derived either from various indices of 'fibre-rich' foods, crude fibre, or dietary fibre using the British food tables. Several of these studies were very small scale and tended to yield non-significant results.

Table 3 summarizes these studies and shows that, in studies where it has been measured, fibre has tended to be associated with a reduction in risk. Eleven studies, for example, of twenty-two have shown that cases reported less 'fibre' than controls, and in only two had they reported eating more. There were no significant differences in nine.

Much of this apparent protective effect of fibre is accounted for by the fact that in twelve of nineteen studies, cases reported eating smaller amounts of vegetables than controls. In the thirteen studies in which cereal consumption was reported, risk was reduced by cereal consumption in three, but increased in three. However, in the largest study of 818 cases in Belgium, starch, fibre, and vegetable consumption were all protective factors, with relative risks for colo-rectal cancer being reduced to $0.71,0.37$, 0.82 and 0.67 respectively in the highest levels of cooked vegetables, raw vegetables, starch and fibre consumption. Peas and beans were associated with increased risk (Tuyns et al. 1987, 1988).

The consistently protective effect of vegetables may reflect the fact that vegetables are a major source of fibre in Western diets. Vegetables also contain numerous flavours and colours, such as flavanoids, tannins, isothiocyanates, indoles and phenols which have been found to reduce the incidence of some chemically-induced cancers (Wattenberg, 1990).

However, a major drawback of case-control studies is that the most common symptoms in large bowel disease are pain and altered bowel function (Cummings, 1981a), which patients may attempt to ameliorate by a change in diet. An attempt to avoid this potential bias is made in case-control studies of diet by asking for details of past dietary habits, rather than present ones. This procedure is impossible to validate with certainty, but circumstantial evidence suggests that recall of past diet is strongly influenced by present dietary habits (Bingham, 1987). The apparently protective effects of fibre and of vegetables, documented in case-control studies may, therefore, be reflecting the effect of cancer rather than the cause. 
Prospective studies. There have been three prospective studies of diet and cancer in which several thousand individuals have been assessed for their consumption of fibre, vegetables or cereals, and then followed up for several years. In the largest, of 265000 Japanese, individuals who later developed colo-rectal cancer reported eating less vegetables and cereals than those who did not (Hirayama, 1981). The 141 individuals who developed colon cancer, of a study of 35000 Californian Seventh Day Adventists, also reported eating less crude fibre and some vegetables than the rest of the population (Stampfer et al. 1987). No significant findings for crude fibre or fibre-related foods have so far been found in a prospective study of 89534 US nurses (Morgan et al. 1988).

More definitive results will be available in several years' time from European collaborative prospective studies of diet and cancer. In these studies, to be carried out in nine European and Scandinavian countries, the food intake of in excess of 500000 individuals will be measured using properly validated methods suitable for the assessment of food intake in individuals (Riboli, 1989). As importantly, accurate methods for the assessment of dietary fibre consumption can now be included, as non-starch polysaccharides (NSP).

\section{DEFINITION AND ANALYSIS OF DIETARY FIBRE (NSP)}

As mentioned previously, various methods for assessing fibre consumption have been used by epidemiologists, and it is only recently that accurate values for fibre in foods, as NSP, have become available (Englyst et al. 1988, 1989). NSP include all the carbohydrate fractions and types of dietary fibre: soluble and insoluble, pectins, gums, hemicelluloses, together with storage polysaccharides such as inulin, guar, gums and exudates (e.g. sterculia, karaya), cellulose, $\beta$-glucans and non-cellulosic polysaccharides. During analysis NSP are hydrolysed into their component sugars and uronic acids, after previous removal of the other main polysaccharide in food, starch. The component sugars and uronic acids are then measured directly by gas-liquid chromatography or a colorimetric procedure to give the NSP or dietary fibre content (Englyst \& Hudson, 1987; Englyst et al. 1987a).

All plant foods except oils and sugars contain NSP, with contents ranging from $1 \mathrm{~g} / \mathrm{kg}$ in cornflour to 690 and $360 \mathrm{~g} / \mathrm{kg}$ in soya-bean bran and wheat bran. Values for some commonly eaten foods are shown in Table 4 . Of these, whole-grain wheat cereals, such as Weetabix, and wholemeal bread are the most concentrated sources, although some leafy vegetables, such as cabbage, and root vegetables and legumes contain appreciable amounts. The NSP content of white rice is very low $(4 \mathrm{~g} / \mathrm{kg})$.

INTAKES OF NSP

To date, only six populations have been studied for their NSP consumption in Scandinavia, Britain and Japan (Table 5). In the UK diet, approximately $10 \%$ of total NSP is supplied by uronic acids, $20 \%$ by cellulose and $68 \%$ by the remaining pentose and hexose sugars.

NSP intake has been related to colon cancer incidence in two of these populations, in Britain and Scandinavia, both of which consume high amounts of meat (150-215 g/d) and fat $(100-150 \mathrm{~g} / \mathrm{d})$. In these populations, protective though weak associations between large bowel cancer occurrence and NSP intake were found. In Britain, the correlation 
Table 4. Non-starch polysaccharide (NSP) content of common foods (from Englyst et al. 1988, 1989)

\begin{tabular}{|c|c|c|c|c|c|}
\hline \multirow[b]{2}{*}{ Food } & \multicolumn{5}{|c|}{$\operatorname{NSP}(g / k g)$} \\
\hline & Total & $\begin{array}{c}\text { Ratio } \\
\text { insoluble: } \\
\text { soluble }\end{array}$ & Cellulose & $\begin{array}{c}\text { Pentose }+ \\
\text { hexose }\end{array}$ & $\begin{array}{c}\text { Uronic } \\
\text { acids }\end{array}$ \\
\hline Apples & 15 & 15 & 5 & 6 & 4 \\
\hline Baked beans & 35 & 7 & 8 & 21 & 6 \\
\hline Cabbage & 27 & 13 & 9 & 11 & 7 \\
\hline Carrots & 25 & 8 & 8 & 9 & 8 \\
\hline Lettuce & 12 & 10 & 5 & 3 & 4 \\
\hline Weetabix & 97 & 21 & 15 & 80 & 2 \\
\hline Oats & 70 & 6 & 6 & 62 & 2 \\
\hline Wholemeal bread & 52 & 33 & 8 & 42 & 2 \\
\hline Brown rice & 19 & $\begin{array}{c}\text { All } \\
\text { insoluble }\end{array}$ & 6 & 9 & 1 \\
\hline White bread & 15 & 7 & 2 & 14 & 0 \\
\hline Cornflakes & 9 & 13 & 3 & 5 & 1 \\
\hline White rice & 4 & $\begin{array}{c}\text { All } \\
\text { insoluble }\end{array}$ & 2 & 3 & 0 \\
\hline
\end{tabular}

Table 5. Non-starch polysaccharide (NSP) intakes of six populations

\begin{tabular}{lccccc}
\hline \hline & \multicolumn{5}{c}{ NSP intake $(\mathrm{g} / \mathrm{d})$} \\
\cline { 2 - 6 } & Total & (SD) & Cellulose & $\begin{array}{c}\text { Pentose }+ \\
\text { hexose }\end{array}$ & $\begin{array}{c}\text { Uronic } \\
\text { acids }\end{array}$ \\
\hline Rural Finland & 18.4 & 7.8 & 4.2 & 12.7 & 1.9 \\
Rural Denmark & 18.0 & 6.4 & 3.7 & 12.1 & 2.2 \\
Helsinki & 14.5 & 5.4 & 3.4 & 9.2 & 2.0 \\
Copenhagen & 13.2 & 4.0 & 3.2 & 8.1 & 1.9 \\
UK & 12.4 & - & 2.6 & 7.9 & 1.8 \\
Japan & 10.9 & - & 3.0 & 4.7 & 3.1 \\
\hline
\end{tabular}

between regional NSP intake and age-standardized colon cancer mortality rates was $-0.74(P<0.05)$, see Fig. 2 . There was no significant association between NSP intake and colo-rectal cancer mortality and the strongest association was with vegetable consumption ( $r$ 0.94) (Bingham et al. 1985).

In the four regions of Scandinavia, Helsinki, Parrikala in rural Finland, Copenhagen and Them in rural Denmark, there was a significant negative association between colo-rectal cancer incidence and NSP intake (Fig. 3), but in contrast to the findings in Britain, this negative association was largely accounted for by cereal consumption, rather than vegetables. In rural Finland, the low cancer area, consumption of cereals, including rye bread made from high extraction flour, was nearly double that of Copenhagen, where cancer rates were highest (IARC Large Bowel Cancer Group, 1982).

Also shown in Table 5 are NSP intakes measured in composite diets derived from the Japanese National Nutrition Survey for 1979 (Kuratsune et al. 1986). Despite their 

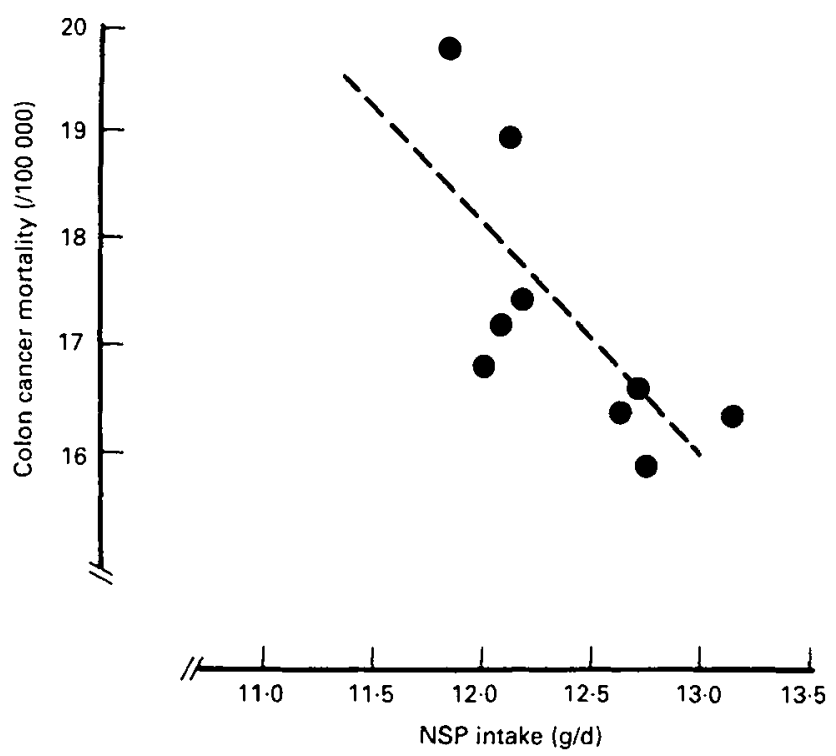

Fig. 2. Age-standardized colon cancer mortality and non-starch polysaccharide (NSP) intake in the nine standard regions of the UK, 1969-1975 (Bingham et al. 1985).

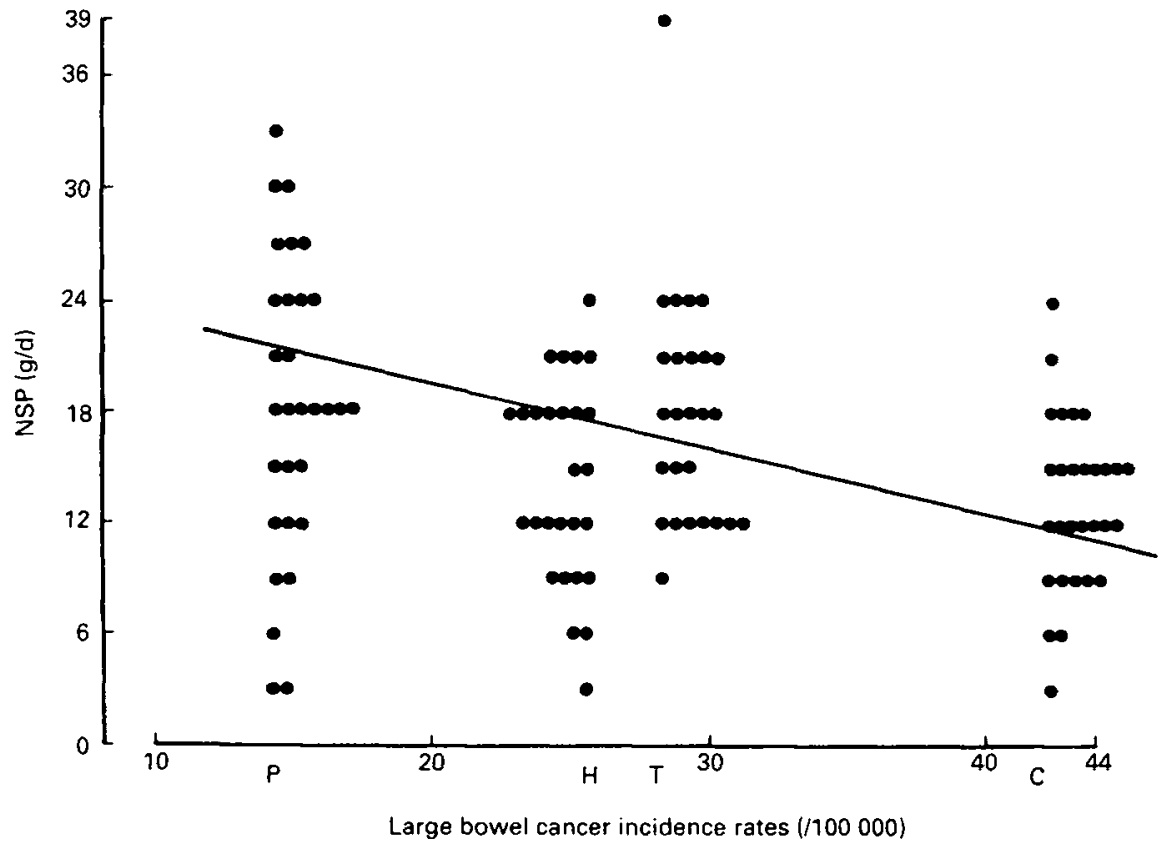

Fig. 3. Age-standardized colon and rectal cancer incidence $r$. non-starch polysaccharide (NSP) intake in four Scandinavian populations $(r-0.78)$ (IARC Large Bowel Cancer Group, 1982). P, Parrikala (Finland); H, Helsinki (Finland); T, Them (Denmark): C, Copenhagen (Denmark). 
comparatively high cereal consumption, the Japanese consume no more NSP than that consumed by European populations: $11 v .12 \mathrm{~g} / \mathrm{d}$, for example, in Britain. The reason for the low NSP content of the Japanese diet is the low NSP content of rice, see Table 4.

In all populations so far studied, remarkably little dietary fibre is found. Table 5 shows that the greatest amount of NSP found in average diets is $18 \mathrm{~g} / \mathrm{d}$. Intakes of NSP based on food consumption level estimates in Finland were also $18 \mathrm{~g} / \mathrm{d}$ (Varo et al. 1984), as were the intakes of Finnish adolescents (Virtanen \& Varo, 1988). This is substantially less than the other major polysaccharide in food, starch.

Starch. Starch is chemically distinct from NSP but contaminates most analytical methods for dietary fibre (James \& Theander, 1980). Resistant starch is a name originally introduced by Englyst for retrograded amylose that is difficult to remove from food samples by normal enzymic hydrolysis without previous treatment with alkali or dimethyl sulphoxide. The amount of resistant starch in a particular food sample is highly dependent on the way in which the sample is treated before analysis; freeze-drying, for example, introduces large amounts (Englyst et al. 1982).

Other forms of starch may also reach the large intestine and may, or may not, contaminate analytical methods for the determination of dietary fibre. Whole or partly milled cereal grains and ungelatinized potato- and banana-starch granules have been classified as 'partially resistant starch', although starch granules, once cooked and gelatinized, are readily digested in the small gut. A further type of partially resistant starch is retrograded amylopectin which can be made to revert on heating to its more digestible form (Englyst \& Cummings, 1987a).

The amount of starch reaching the large intestine has been assessed in careful studies using volunteer patients with an ileostomy, a fistula constructed so that the ileum opens onto the abdominal wall, usually after surgical removal of the colon and rectum. In these patients, known amounts of different starches were fed and the ileostomy fluid obtained from the small bowel analysed for its content of undigested starch (Englyst \& Cummings, $1985,1986,1987 b$ ). These studies have shown that substantial amounts of starch may reach the large intestine, but the amount that does so depends on cooking, processing and even the ripeness of food. Of the starch in bananas $90 \%$, in the form of starch granules, is not digested in the small gut, so that when only 'just ripe' bananas, with green tips, are eaten as much starch as an average daily intake of NSP may reach the large intestine (Englyst \& Cummings, 1986). Of the starch in white-flour products, cornflakes, and freshly cooked potatoes $3-5 \%$ is not digested, but this increases to $12 \%$ when potatoes are cooked and then cooled before eating (Englyst \& Cummings, 1985, 1987b).

Large quantities of starch may, therefore, reach the large intestine. For this reason it has been argued that starch should be included in the definition of 'dietary fibre', despite the fact that one of the original and leading pioneers of the dietary fibre hypothesis, $H$. R. Trowell, has stated that 'starch was never named . . . as a constituent of dietary fibre' (Trowell, 1985). As yet little work has been done on the effect of starch on bowel habit, although in vitro and in vivo studies suggest that it behaves differently to NSP on becoming available for fermentation by the large bowel flora (see p. 165).

\section{MECHANISMS IN COLO-RECTAL CANCER}

The physiological importance of starch, particularly in cooked and cooled foods, has only recently been realized and there is consequently little epidemiological information 
available on amounts consumed. Nevertheless, the available information suggests that NSP and possibly starch interact with meat and other aspects of diet, particularly meat and fat, in affecting risk from large bowel cancer. In considering possible mechanisms whereby this interaction in dietary habits could be important in cancer aetiology, the colonic flora and the control of its activity by diet play a key role.

The colon is host to a large and diverse commensal flora of anaerobic bacteria that until recently has attracted little attention in medical microbiology. However, with $>400$ species (Finegold et al. 1983) the colonic flora can be considered as an important organ in its own right, with a flexibility and potential for metabolic transformations at least as great as that of the liver. Enzymes are readily induced by changes in the metabolic environment and a wide variety of substances can be hydrolysed, reduced, degraded, or synthesized. All of them may be important in the generation of carcinogens or in degrading or re-activating carcinogens secreted in bile.

The importance of diet is due to the fact that the major control on the metabolic environment of the flora is via residues entering the large gut from the small bowel. These in turn are determined by dietary intakes, particularly protein and carbohydrate.

Carbohydrate entering the large bowel stimulates anaerobic fermentation, leading to the production of short-chain fatty acids (SCFA), acetate, propionate and butyrate, gas, and an increase in microbial cell mass. The SCFA produced are absorbed by the intestinal mucosa, where they stimulate sodium absorption and bicarbonate secretion (Cummings, 1981b). Carbohydrates stimulating fermentation include in the caecum the laxative lactulose and, in lactase-deficient individuals, lactose. Normally, however, sugars are absorbed in the small gut and it is the polysaccharides that are quantitatively the most important.

Fermentation has a number of important consequences in large bowel physiology and possible implications for protection against large bowel cancer. First, the increase in bacterial cell mass results in an increase in faecal weight (Stephen \& Cummings, 1980). Cereal fibre, from bran and some resistant starch, has an additional effect because it is only partly fermented and the residual polysaccharides absorb water, also contributing to faecal bulking (McBurney et al. 1985). With the increase in faecal weight, transit time is reduced and the contents of the large bowel lumen are diluted, which would reduce the time putative carcinogens are in contact with the large bowel mucosa, an effect originally suggested by Burkitt (1969) to explain the way in which dietary fibre would be protective against colon cancer.

These protective mechanisms depend on the assumption that the initiating factors against which NSP and starch are thought to protect are present in the faecal stream, and there is accumulating evidence that faeces do contain at least mutagens, and possibly carcinogens.

Faecal mutagenicity. Faecal mutagenicity may be assessed with the Ames test, TA 98 detecting frameshift mutations, and TA 100 base pair substitutions (Maron \& Ames, 1983). Both strains may be tested following stimulation with the microsomal fraction S9 to stimulate in vivo metabolic activation. Not all individuals produce mutagenic samples, the proportion who do so in any one population depending to a large extent on the solvent used to prepare sterile extracts from faeces (Schiffman, 1986).

Using organic solvents, eighteen of fifty individuals in Helsinki exhibited high faecal mutagenicity. Fifteen of these individuals then took part in an intervention study, whereby fibre intake from whole-grain bread was increased by $11 \mathrm{~g} / \mathrm{d}$ for 4 weeks. Stool 
bulk increased by $35 \%$ and faecal mutagenicity decreased by $2 \cdot 5-4 \cdot 5$-fold (Reddy $e$ t al. 1987).

The standard Ames test is open to difficulties when used for faecal extract testing, but Venitt (1988; Venitt et al. 1986), using methods designed to overcome both toxic and nutritive factors in faecal extracts, also found a reduction in faecal mutagenicity with bran, albeit in only one subject in a preliminary study. Kuhnlein et al. (1983), using aqueous faecal extracts, has also shown reductions in faecal mutagenicity with cellulose and with pectin in rats.

The fact that different results are obtained from different extracts in Ames testing suggests that faeces contain a variety of mutagens (Schiffman, 1987). Polycyclic hydrocarbons, phenols, and $\mathrm{N}$-nitrosocompounds are possible candidates, but most attention has been focused recently on the fecapentaenes and heterocyclic amines.

Fecapentaenes. Fecapentaenes are compounds with a central pentaene structure, and a chain length of 12 or 14 . They are produced by the large bowel bacterial fiora, possibly by Bacteroides, the most common species in the human colon (Finegold et al. 1983). The precursor(s) is unknown. Fecapentaenes can now be isolated from faeces, thus avoiding the necessity for mutagenicity testing, and a synthetic fecapentaene 12 (FP 12) has now been synthesized (Schiffman, 1987).

No relationship between dietary fibre intake and fecapentaene excretion was detected in a questionnaire study, although high excreters were less likely to be consuming supplements of vitamins $C$ and $E$ (Schiffman, 1987). Little work has otherwise been done on the interaction between dietary fibre and fecapentaenes, and two recent studies suggest that its importance in colon cancer may be limited. Although FP 12 has been shown to exhibit a high degree of genotoxicity, for example, causing DNA single-strand breaks and sister chromatid exchanges, it has not been shown to be a carcinogen in rodent assays (Ward et al. 1988). Second, patients with colo-rectal cancer have been shown to excrete substantially less fecapentaenes than patients without colo-rectal cancer (Schiffman et al. 1988).

Heterocyclic amines. A number of heterocyclic amines are formed in meat and fish cooked at relatively low temperatures. After microsomal activation these were found to be highly mutagenic in the Ames test and carcinogenic in several organs, particularly the liver (Sugimura, 1985). The quinoline derivatives, such as IQ, MeIQx, and MeIQ, result probably from Maillard reactions between a hexose such as glucose and an amino acid with linkage of the resulting Strecker aldehyde with creatinine (Sjodin et al. 1985). MeIQ and IQ are damaging to mouse colon cells in vivo (Bird \& Bruce, 1984) and IQ induces large intestinal tumours in mice (Ohgaki et al. 1986). MeIQx can be extracted from faeces using blue cotton which can adsorb organic complexes having three or greater numbers of fused aromatic rings. Hayatsu et al. (1986) showed an increase in faecal mutagenicity in volunteers subsequent to a meal of $150 \mathrm{~g}$ fried beefburgers, but could not identify the major mutagenic component as MeIQx. This finding would have offered a direct link with the epidemiological association between meat consumption and colon cancer. No studies as yet have investigated the effect of fibre on heterocyclic amine metabolism. Fermentation does, however, have marked effects on two other substances present in the large bowel, ammonia, and bile acids.

Ammonia. The main product of bacterial metabolism of nitrogenous residues is ammonia, which enhances cell proliferation, alters DNA synthesis, and has been implicated in large bowel carcinogenesis (Visek, 1978). When carbohydrate availability 
is limited, ammonia concentrations increase in vitro (Cummings et al. 1979), but in the presence of active fermentation ammonia is used for bacterial protein synthesis and faecal ammonia concentration falls (Macfarlane et al. 1986). Diets high in meat generally also contain little starch and NSP and can, therefore, be expected to increase ammonia concentration partly by an increase in available nitrogen and because fermentation is limited. It was also suggested that high-protein diets have an added effect via increased diffusion of urea into the colon when blood urea levels rise in response to high-protein diets (Wolpert et al. 1971). However, in humans, colonic perfusion experiments showed that the large bowel mucosa is virtually impermeable to urea, and studies in which plasma urea was labelled with ${ }^{15} \mathrm{~N}$ showed that endogenous urea makes only a small contribution to total faecal $\mathrm{N}$ content, about $8 \%$ (Wrong et al. 1985). Levels of faecal ammonia have not yet been measured on an epidemiological basis.

$p H$ and bile acids. Fermentation may also affect risk of colon cancer via its effect on $\mathrm{pH}$ and bile acids. Bile acids are thought to promote colo-rectal tumours, although the actual mechanism involved is uncertain. Proliferation, via increased ornithine decarboxylase ( $E C$ 4.1.1.17) activity or protein kinase $C$ has been suggested (Takano et al. 1981; De Rubertis et al. 1984; De Rubertis \& Craven, 1987; Fitzer et al. 1987; Sakata, 1987). Bile acids alone, however, are unlikely to affect colon cancer risk because there is no difference in faecal bile acid output either between cases and healthy matched controls, or between individuals living in a high-risk area compared with a low one (Setchell et al. 1987).

Cereal fibre, from bran, dilutes faecal bile acid content, although total output is increased (Cummings et al. 1976). It has also been proposed that a key step in the development of bowel cancer is the conversion of primary to secondary bile acids (Thornton, 1981). The SCFA produced during fermentation are thought to lower $\mathrm{pH}$, and as a result this conversion is inhibited (Thornton, 1981). However, other considerations are important. In the perfused colon, there is little damaging effect of deoxycholic acid at pH 5.9, whereas damage can be extensive at pH 7.9 (Rafter et al. 1986). This effect has been attributed to the insolubility of bile acids at low $\mathrm{pH}$, so that bile acid concentration in faecal water may be more indicative of risk (Bruce, 1987).

Gas production. The gases carbon dioxide, hydrogen, and in some individuals methane, are other end-products of fermentation. $\mathrm{H}_{2}$ diffuses into the bloodstream, and excretion in breath has been extensively used as a marker of oral caecal transit time in humans. Attempts have also been made to quantify the amount of carbohydrate reaching the large gut by comparing breath $\mathrm{H}_{2}$ production with a known amount of fermentable carbohydrate, such as lactulose (Bond \& Levitt, 1975). However, this is unlikely to be an accurate procedure, since there are other alternatives for disposal of $\mathrm{H}_{2}$ in fermentation, depending partly on the bacterial flora, including methanogenic bacteria (Christl et al. 1989) which themselves are in competition with sulphate-reducing bacteria for $\mathrm{H}_{2}$ (Gibson et al. 1988a). The end-product of the activities of sulphate-reducing bacteria, hydrogen sulphide, is highly toxic and may be important in the aetiology of large gut disease (Florin et al. 1989). Only 15\% of rural black South Africans at low risk of colon cancer carry sulphate-reducing bacteria, compared with $70 \%$ of samples from British individuals (Gibson et al. 1988 b). Correspondingly $84 \%$ of black Africans are methane producers compared with $52 \%$ of whites (Segal et al. 1988). Methanogenesis appears, therefore, not to be risk factor for colon cancer, contrary to previous observations (Haines et al. 1977). 
SCFA and butyrate production. In addition to their probable effect on $\mathrm{pH}, \mathrm{SCFA}$ are involved in the nutrition of the large bowel mucosa, and in the control of cellular proliferation and differentiation.

Approximately 60,20 and $20 \%$ molar ratios of acetate, propionate and butyrate are formed during fermentation in the human large gut (Cummings, 1981b). Molar ratios can, however, be varied in vitro, according to the substrate. In batch cultures of human faecal slurries, $29 \%$ of butyrate can be produced from starch, compared with 8,3 and $2 \%$ from an arabinogalactan, a xylan, and pectin (Englyst et al. 1987b). This effect of starch fermentation in increasing butyrate production has also been shown in vivo. Eleven individuals were fed on the glucosidase inhibitor acarbose in order to induce starch malabsorption in the small gut. Molar ratios of butyrate in faeces increased from an average of $21 \%$ without starch malabsorption to $30 \%$ with malabsorption, a $50 \%$ increase. There was no change in the molar ratio of acetate $(41 \%)$, and a fall in propionate production, from 27 to $21 \%$ (Scheppach et al. 1988).

SCFA are absorbed from the large gut, less butyrate being found in the human portal vein (Cummings et al. 1987). In most species, butyrate is used preferentially to acetate and propionate as a substrate for energy metabolism in the large bowel epithelium (Cummings, 1981b). In the isolated human colonocyte, butyrate accounts for about $75 \%$ of oxygen consumption, and glucose is able to replace butyrate to a lesser extent in the proximal colon compared with the distal colon. This, together with less ketone-body formation, suggests that butyrate is a major source of energy for the distal colonic mucosa (Roediger, 1980). Acetate was not investigated in these studies, due to an absence of effect in the rat colonocyte.

In the conventional but not germ-free rat, wheat bran and ispaghula significantly enhance epithelial cell proliferation compared with animals fed on fibre-free diets (Goodlad et al. 1989). SCFA, however, directly enhance proliferation rates in both germ-free and conventional rats (Sakata, 1987). Intracolonic infusions of SCFA have also been shown to promote healing in anastomoses of the surgically divided colon of rats (Rolandelli et al. 1986). This beneficial effect of SCFA on proliferation and healing is perhaps to be expected, if they are to be considered as nutritional factors for colonic epithelial cells. Excessive cell proliferation is a putative aetiological factor in carcinogenesis, but SCFA at physiological levels are unlikely to promote epithelial proliferation beyond the normal range (Sakata, 1987).

In cultured cell lines, butyrate is a well recognized anti-proliferative agent. At the 1-2 mM level, it acts directly as an inhibitor of DNA synthesis and cell growth, mainly via inhibition of histone deacetylase. Other SCFA are much less active in this respect (Kruh, 1982). The effect is reversible, with a $24 \mathrm{~h}$ lag in $G_{1}$ phase before normal growth rates are resumed after removal of butyrate from culture media (Smith, 1986). Acetylation may be a general mechanism for relaxing DNA, allowing access for repair enzymes; ultra violet radiation damage repair is enhanced and survival increased in human adenocarcinoma cell lines exposed to butyrate for example (Smith, 1986).

Butyrate is also a known differentiation-inducing agent, reducing cloning efficiency and increasing the expression of membrane glycoproteins such as alkaline phosphatase (EC 3.1.3.1) and carcino-embryonic antigen in some human colo-rectal cancer cell lines (Chung et al. 1985; Whitehead et al. 1986). Other SCFA have little effect compared with butyrate (Whitehead et al. 1986). The effects of butyrate, however, vary amongst different cell lines; in one line derived from familial adenomatous polyposis, butyrate 
seemed to select for increased malignancy. This effect, however, was not seen in another line derived from a patient with non-inherited, sporadic colon cancer (Berry \& Paraskeva, 1988). Very large doses $(100-200 \mathrm{mmol} / \mathrm{h})$ of butyrate added to drinking water have been reported to increase chemical carcinogenesis in rats treated with DMH (Freeman, 1986). The effects of butyrate on microsomal activation of DMH, and on a direct-acting carcinogen in the large bowel have not been determined.

Butyrate may, therefore, be involved in protection against carcinogenesis in the colon and rectum, the only organs in the body exposed to elevated levels. Two small studies have shown lowered faecal butyrate levels of $8 v .12 \%$ total SCFA in patients with colo-rectal cancer compared with healthy controls (Vernia et al. 1988; Bonnen et al. 1989).

\section{SUMMARY AND CONCLUSIONS}

The cause of human colo-rectal cancer is unknown, although international and racial comparisons suggest that diet may be important. Within populations, risk of cancer is also affected by genetic factors which remain to be elucidated. Dietary fibre and NSP consumption is not always high in populations at low risk of colo-rectal cancer, but rates are fast increasing with westernization (and meat and fat consumption) in Japan.

The suggestion that dietary fibre is protective in colo-rectal cancer is based on the fact that cereal fibre from bran increases faecal weight, dilutes large intestinal contents, and speeds up transit time. In animal models, bran reduces the number of tumours induced by chemical carcinogens, and cellulose may have a similar effect. The faeces of some individuals contain mutagens, some of which have been identified as fecapentaenes and heterocyclic amines. Bran reduces faecal mutagenicity, although the mutagen concerned is unknown.

Most dietary fibre is fermented in the large gut by anaerobic bacteria and little remains in faecal matter. Recent observations have shown that substantial amounts of starch survive digestion in the small bowel and are available also for fermentation in the large gut. The metabolic consequences of fermentation may be important in carcinogenesis via altered $\mathrm{N}$ metabolism, SCFA production, and $\mathrm{pH}$ reduction. Methane is also produced in some individuals, but, contrary to previous findings, is not a risk factor for large bowel cancer. Starch appears to be beneficial as a substrate for fermentation because yields of the SCFA butyrate are increased both in vitro and in vivo. Butyrate is an energy substrate for the colonic mucosa and an anti-proliferative and differentiating agent in cell culture lines. Possible mechanisms whereby starch and NSP may protect against colo-rectal cancer, therefore, exist.

The majority of individual case-control epidemiological studies suggest that fibrecontaining foods are protective in colo-rectal cancer, although this effect is largely due to vegetable, rather than cereal, consumption. Case-control studies of diet and large bowel cancer may, however, reflect the effect rather than the cause of the disease, so that confirmation of the possible protective effects of starch and NSP is needed from accurate prospective studies both of diet and associated risk factors. 


\section{REFERENCES}

Armstrong, B. \& Doll, R. (1975). Environmental factors and cancer incidence in different countries, with special reference to dietary practices. International Journal of Cancer 15, 617-631.

Baker, S. J., Fearon, E. R., Nigro, J. M., Hamilton, S. R., Preisinger, A. C. Jessup, J. M., Vantuinen, P., Ledbetter, D. H., Barker, D. F., Nakamura, Y., Wright, R. \& Vogelstein, B. (1989). Chromosome 17 deletion and P53 gene mutation in colorectal carcinomas. Science 244, 217-221.

Berry, R. D. \& Paraskeva, C. (1988). Expression of CEA by adenoma and carcinoma derived epithelial cell lines. Carcinogenesis 9, 447-450.

Berta, J. L., Coste, T., Rautureau, S., Bataille, M. \& Pequignot, G. (1985). Dietary survey in colorectal cancer: results of a case-control study. Gastroenterology and Clinical Biology 9, 348-353.

Bingham, S. (1987). The dietary assessment of individuals: methods, accuracy, new techniques and recommendations. Nutrition Abstracts and Reviews 57, 705-742.

Bingham. S., Williams, D. R. R. \& Cummings, J. H. (1985). Dietary fibre consumption in Britain: new estimates and their relation to large bowel cancer mortality. British Journal of Cancer 52, 399-402.

Bird, R. P. \& Bruce, W. R. (1984). Colonic damage by mutagenic amines. Journal of the National Cancer Institute 73, 237-240.

Bjelke, E. (1971). Case control study of cancer of the stomach, colon and rectum. In Oncology 1970: being the Proceedings of the Tenth International Cancer Congress, vol. 5, pp. 320-334 [R. L. Clark, R. W. Cumley, J. E. McCay and M. M. Copeland, editors]. Chicago, Ill: Yearbook Medical Publishers Inc.

Bond, J. H. \& Levitt, M. D. (1975). Fate of soluble carbohydrate in the colon of rats and man. Journal of Clinical Investigation 57, 1158-1164.

Bonnen, H., Clausen, M. R. \& Mortensen, P. B. (1989). Colonic concentration and production of butyrate from dietary fibre is decreased in patients with adenomas in the colon. Gastroenterology 96, A51.

Bristol, J. B., Emmett, P. M., Heaton, K. W. \& Williamson, R. C. N. (1985). Sugar, fat and the risk of colorectal cancer. British Medical Journal 291, 1467-1470.

Bruce, W. R. (1987). Recent hypotheses for the origin of colon cancer. Cancer Research 47, 4237-4242.

Burkitt, D. P. (1969). Related disease - related cause. Lancet ii, 1229-1231.

Calder, J. F., Wachira, M. E., Van Sant, T., Malik, M. S. \& Bowry, R. N. (1980). Diverticular disease, carcinoma of the colon and diet in urban and rural Kenyan Africans. Diagnostic Imaging 49, 23-28.

Christl, S., Murgatroyd, P. R., Gibson, G. R. \& Cummings, J. H. (1989). Total hydrogen and methane production from fermentation in man measured in a whole body calorimeter. Clinical Science 77, 37 (Abstr.).

Chung, Y. S., Song, I. S., Erickson, R. H., Sleisenger, M. H. \& Kim, Y. S. (1985). Effect of growth and sodium butryate on brush border membrane associated hydrolases in human colorectal cancer cell lines. Cancer Research 45, 2976-2982.

Cummings, J. H. (1981a). Dietary fibre and large bowel cancer. Proceedings of the Nutrition Society 40, 7-14.

Cummings, J. H. (1981b). Short chain fatty acids in the human colon. Gut 22, 763-779.

Cummings, J. H., Hill, M. J., Bone, E. S., Branch, W. J. \& Jenkins, D. J. A. (1979). The effect of meat protein and dietary fiber on colonic function and metabolism. II. Bacterial metabolites in feces and urine. American Journal of Clinical Nutrition 32. 2094-2101.

Cummings, J. H., Hill, M. J., Jenkins, D. J. A., Pearson, J. R. \& Wiggins, H. S. (1976). Changes in fecal composition and colonic function due to cereal fiber. American Journal of Clinical Nutrition 29, 1468-1473.

Cummings, J. H., Pomare, E. W., Branch, W. J., Naylor, C. P. E. \& Macfarlane, G. T. (1987). Short chain fatty acids in human large intestine, portal, hepatic and venous blood. Gut 28, 1221-1227.

Dales, L. G., Friedman, G. P., Ury, H. K., Grossman, S. \& Williams, S. (1978). A case control study of relationships of diet and other traits to colorectal cancer in American Blacks. American Journal of Epidemiology 109, 132-144.

De Rubertis, F. R. \& Craven, P. A. (1987). Relationship of bile salt stimulation of colonic epithelial phospholipid turnover and proliferative activity: role of activation of protein kinase C. Preventive Medicine 16, 572-579.

De Rubertis, F. R.. Craven, P. A. \& Saito, R. (1984). Bile salt stimulation of colonic epithelial proliferation. Journal of Clinical Investigation 74, 1614-1624.

Englyst, H. N., Bingham, S. A., Runswick, S. A., Collinson, E. \& Cummings, J. H. (1988). Dietary fibre (NSP) in fruit, vegetables and nuts. Journal of Human Nutrition and Dietetics 1, 247-286.

Englyst, H. N., Bingham, S. A., Runswick, S. A., Collinson, E. \& Cummings, J. H. (1989). Dietary fibre (NSP) in cereals and cereal products. Journal of Human Nutrition and Dietetics 2, 253-271. 
Englyst, H. N. \& Cummings, J. H. (1985). Digestion of the polysaccharides of some cereal foods in the human small intestine. American Journal of Clinical Nutrition 42, 778-787.

Englyst, H. N. \& Cummings, J. H. (1986). Digestion of the carbohydrates of banana in the human small intestine. American Journal of Clinical Nutrition 44, 42-50.

Englyst, H. N. \& Cummings, J. H. (1987a). Digestion of the polysaccharides of potato in the small intestine of man. American Journal of Clinical Nutrition 45, 423-431.

Englyst, H. N. \& Cummings, J. H. (1987b). Resistant starch, a 'new' food component: a classification of starch for nutritional purposes. In Cereals in a European Context, pp. 221-223 [1. D. Morton, editor]. Chichester: Ellis Horwood.

Englyst, H. N., Cummings, J. H. \& Wood, R. (1987a). Determination of dietary fibre in cereals and cereal products - collaborative trials. Part III: Study of further simplified procedures. Journal of the Association of Public Anulysts 25, 73-110.

Englyst, H. N., Hay, S. \& Macfarlane, G. T. (1987b). Polysaccharide breakdown by mixed populations of human faecal bacteria. FEMS Microbiology Ecology 95, 163-171.

Englyst, H. N. \& Hudson, G. J. (1987). Colorimetric method for routine measurement of dietary fibre as non-starch polysaccharides. A comparison with gas-liquid chromatography. Food Chemistry 24, 63-76.

Englyst, H., Wiggins, H. S. \& Cummings, J. H. (1982). Determination of the NSP in plant foods by GLC of constituent sugars as alditol acetates. Analyst 107, 307-318.

Esser, W., Weithofer. G. \& Block, R. (1980). Zur Bedeutung des Fett und Rohtasergahalts der Nahrung für die Entetchung des Kolonkarzinoms. Zeitschrifi für Gastroenterologie 18, 1-8.

Finegold, S. M., Sutter, V. L. \& Mathisen, G. E. (1983). Normal indigenous intestinal flora. In Human Intestinal Microflora in Health and Disease, pp. 3-31 [D. J. Hentges, editor]. New York: Academic Press.

Fitzer, C. J., O'Brian, C. A.. Guillem, J. G. \& Weinstein, I. B. (1987). The regulation of protein kinase C by chenodeoxycholate, deoxycholate and several structurally related bile acids. Carcinogenesis 8, 217-220.

Florin. T. H. J., Neale, G. \& Cummings, J. H. (1989). Dietary and endogenous sulphate losses from the upper gastrointestinal tract. Clinical Science 77, 6-7 (Abstr.).

Frecman, H. J. (1986). Effects of differing concentrations of sodium butyrate on DMH induced rat intestinal neoplasia. Gastroenterology 91, 596-602.

Gibson, G. R., Cummings, J. H. \& Macfarlane, G. T. (1988a). Competition for hydrogen between sulphate reducing bacteria and methanogenic bacteria from the human large intestine. Journal of Applied Bacteriology 65, 241-247.

Gibson. G. R., Macfarlane, G. T. \& Cummings, J. H. (1988b). Occurrence of sulphate-reducing bacteria in human faeces and the relationship of dissimilatory sulphate reduction to methanogenesis in the large gut. Journal of Applied Bacteriology 65, 103-111.

Goodlad, R. A., Ratcliffe, B., Fordham, J. P. \& Wright, N. A. (1989). Does dietary fibre stimulate intestinal epithelial cell proliferation in germ-frec rats? Gut 30, 820-825.

Graham, S., Dayal, H., Swanson. M., Mittelman, A. \& Wilkinson, G. (1978). Diet in the epidemiology of cancer of the colon and rectum. Journal of the National Cancer Institute 61, 709-714.

Graham, S., Marshall, J., Haughley, B., Mittelman, A.. Swanson, M., Zielezny, M., Byers, T., Wilkinson, G. \& West, D. (1988). Dietary epidemiology of cancer of the colon in western New York. American Journal of Epidemiology 128, 490-503.

Haenzel, W., Berg, J. W., Segi, M., Kurihara, M. \& Lock, F. B. (1973). Bowel cancer in Hawaii Japanese. Journal of the National Cancer Institute 51, 1765-1779.

Haines. A., Metz, G., Dilawari, J.. Blendis, L. \& Wiggins, H. (1977). Breath methane in patients with cancer of the large bowel. Lancet $\mathbf{i j ,} 481-483$.

Hayatsu, H. . Hayatsu, T. \& Wataya, Y. (1986). Use of blue cotton for detection of mutagenicity in human faeces excreted after ingestion of cooked meat. Environmental Health Perspectives 67, 31-34.

Higginson, J. (1966). Etiological factors in gastrointestinal cancer in man. Journal of the National Cancer Institute 37, $527-545$.

Higginson, J. \& Oettle, A. G. (1960). Cancer incidence in the Bantu and Cape coloured race of South Africa. Journal of the National Cancer Institute 24, 584-671.

Hirayama, T. (1981). A large scale cohort study on the relationship between diet and selected cancers of digestive organs. In Banbury Report 7, pp. 409-429 [W. R. Bruce, P. Correa, M. Lipkin, S. R. Tannenbaum and T. D. Wilkin, editors]. Cold Spring Harbor, NY: Cold Spring Harbor Láboratory.

Hunter, K., Linn, M. W. \& Harris, R. (1980). Dietary patterns and cancer of the digestive tract in older patients. Journal of the American Geriatric Society 28, 405-409. 
IARC Large Bowel Cancer Group (1982). Second IARC International Collaborative Study on diet and large bowel cancer in Denmark and Finland. Nutrition and Cancer 4, 3-79.

Ip, C. (1978). Fat and essential fatty acids in mammary carcinogenesis. American Journal of Clinical Nutrition 45, 218-224.

Jain, M., Cook, G. M., Davis, F. G., Brace, M. G., Howe, G. R. \& Miller, A. B. (1980). A case control study of diet and colo-rectal cancer. International Journal of Cancer 26, 757-768.

James, W. P. T. \& Theander, O. (editors) (1980). In The Analysis of Dietary Fibre in Food. New York: Marcel Dekker Inc.

Kruh, J. (1982). Effects of sodium butyrate, a new pharmacological agent, on cells in culture. Molecular and Cellular Biochemistry 42, 65-82.

Kuhnlein, U., Gallagher, R. \& Freeman, H. J. (1983). Effects of purified cellulose and pectin fiber diets on mutagenicity of feces and luminal contents of stomach, small and large bowel in rats. Clinical Investigative Medicine 6, 253-260.

Kune, S., Kune, G. A. \& Watson, L. F. (1987). Case control study of dietary etiological factors: the Melbourne colorectal cancer study. Nutrition and Cancer 9, 21-42.

Kuratsune, M., Honda, T., Englyst, H. N. \& Cummings, J. H. (1986). Dietary fibre in the Japanese diet as investigated in connection with colon cancer risk. Japanese Journal of Cancer Research 77, 736-738.

Lee, H. P., Gourley, L., Duffy, S. W., Esteve, J., Lee, J. \& Dom, N. E. (1989). Colorectal cancer and diet in an Asian population - a case control study among Singapore Chinese. International Journal of Cancer $\mathbf{4 3}$, 1007-1016.

Lopez, E., Derivi, S. \& Mendez, M. (1986). The relation between cancer of the colon and rectum and nutrition in Rio de Janeiro. Archives of Latin American Nutrition 36, 282-285.

Lyon, J. L., Mahoney, A. W., West, D. W., Gardner, J. W., Smith, K. R., Sorenson, A. W. \& Stanish, W. (1987). Energy intake: its relationship to colon cancer risk. Journal of the National Cancer Institute 78, 853-861.

McBurney, M. I., Horvath, P. J., Jeraci, J. L. \& Van Soest, P. J. (1985). Effect of in vivo fermentation using human faecal inoculum on the water holding capacity of dietary fibre. British Journal of Nutrition 53, 17-24.

Macfarlane, G. T., Cummings, J. H. \& Allison, C. (1986). Protein degradation by human intestinal bacteria. Journal of General Microbiology 132, 1647-1656.

McKeown-Eyssen, G. E. \& Bright-See, E. (1985). Dietary factors in colon cancer: international relationships. An update. Nutrition and Cancer 7, 251-253.

Macquart-Moulin, G., Riboli, E., Cornee, J., Charnay, B., Berthezene, P. \& Day, N. (1986). Case control study on colorectal cancer and diet in Marseilles. International Journal of Cancer 38, 183-191.

Manousos, O., Day, N. E., Trichopoulos, D., Gerovassilis, F., Tzonou, A. \& Polychronopoulou, A. (1983). Diet and colorectal cancer: a case control study. International Journal of Cancer 32, 1-5.

Maron, D. M. \& Ames, B. N. (1983). Revised methods for the Salmonella mutagenicity test. Mutation Research 113, 173-215.

Martinez, I., Torres, R., Frias, Z., Colon, J. R. \& Fernandez, N. (1979). Factors associated with adenocarcinomas of the large bowel in Puerto Rico. Advances in Medical Oncology Research \& Education $3,45-52$.

Miller, A. B., Howe, G. R., Jain, M., Craib, K. J. P. \& Harrison, L. (1983). Food items and food groups as risk factors in a case control study of diet and colorectal cancer. International Journal of Cancer 32, 155-161.

Minowa, M. , Bingham, S. \& Cummings, J. H. (1983). Dietary fibre intake in Japan. Human Nutrition: Applied Nutrition 37A, 113-119.

Modan, B., Barell, V., Lubin, F., Modan, M., Greenberg, R. A. \& Graham, S. (1975). Low fiber intake as an etiologic factor in cancer of the colon. Journal of the National Cancer Institute 55, 15-18.

Morgan, J. W., Frazer, G. E., Phillips, R. L. \& Andrews, M. H. (1988). Dietary factors and colon cancer incidence amongst Seventh Day Adventists. American Journal of Epidemiology 128, 918A.

Moskovitz, M., White, C., Barnett, R. N., Stevens, S., Russell, E., Vargo, D. \& Flock, M. H. (1979). Diet, fecal bile acids and neutral sterols in carcinoma of the colon. Digestive Diseases Sciences 24, 746-751.

Muir, C., Waterhouse, J., Mack, T., Powell, J. \& Whelan, S. (1987). Cancer Incidence in Five Continents. V. IARC Scientific Publication no. 88. Lyon: International Agency for Research on Cancer.

Nakaji, S., Ohta, M., Ishiguro, S., Munakata, A. \& Yoshida, Y. (1989). An epidemiological study on relationship between intake of dietary fiber and colorectal cancer. Gastroenterology 96, A359.

Ohgaki, H., Hasegawa, H., Kato, T., Suenaga, M., Ubakata, M., Sato, S., Takayama, S. \& Sugimura, T. (1986). Carcinogenicity in mice and rats of heterocyclic amines in cooked foods. Environmental Health Perspectives 67, 129-134. 
O'Sullivan. K. R., Mathias, P. M., Tobin, A. \& O'Morain, C. (1990). The association between diet and colorectal polyps and cancer in an Irish population. Proceedings of the Nutrition Society 49, 41A.

Perisse, J., Sizaret, F. \& Francois, P. (1969). The effect of income in the structure of the diet. FAO Nutrition Newsletter 7, 1.

Phillips, R. L. (1975). Role of life style and dietary habits in risk of cancer among Seventh Day Adventists. Cancer Research 35, 3513-3522.

Phillips, R. L. \& Snowdon, D. A. (1983). Association of meat and coffee use with cancer of the large bowel, breast and prostate among Seventh Day Adventists. Cancer Research 43, Suppl. 2403S-2408S.

Pickle, L. W., Greene. M. H., Ziegler, R. G., Toledo, A., Hoover, R., Lynch, H. T. \& Fraumeni, J. F. (1984). Colorectal cancer in rural Nebraska. Cancer Research 44, 363-369.

Pilch, S. (editor) (1987). Physiological Effects and Health Consequences of Dietary Fiber. Bethesda, Maryland, USA: FASEB.

Potter, J. D. \& McMichael. A. J. (1986). Diet and cancer of the colon and rectum - a case-control study. Journal of the National Cancer Institute 76, 557-569.

Rafter, J. J., Eng, V. W. S., Furrer, R., Medline, A. \& Bruce, W. R. (1986). Effects of calcium and pH on mucosal damage produced by deoxycholic acid in the rat colon. Gut 27, 1320-1329.

Reddy, B. S., Sharma, C., Simi, B., Engle, A., Laakso, K., Puska, P. \& Korpela, R. (1987). Effect of dietary fiber on fecal mutagens and bile acids in healthy subjects. Cancer Research 47, 644-648.

Riboli, E. (1989). Prospective Studies on Diet and Cancer in Europe. Report of On-going Activities no. 1. Lyon: International Agency for Research on Cancer.

Roediger, W. E. W. (1980). Role of anaerobic bacteria in the metabolic welfare of the colonic mucosa in man. Gut 21, 793-798.

Rolandelli, R. H., Koruda, M. J., Settle, R. G. \& Rombeau, J. L. (1986). Effects of intraluminal infusion of SCFA on the healing of colonic anastomosis in the rat. Surgery $100,198$.

Sakata, T. (1987). Stimulatory effects of short chain fatty acids on epithelial cell proliferation in the rat intestine. British Journal of Nutrition 58, 95-103.

Scheppach, W., Fabian, C., Sachs, M. \& Kasper, H. (1988). Effect of starch malabsorption on fecal SCFA excretion in man. Scandinavian Journal of Gastroenterology 23, 755-759.

Schiffman, M. H. (1986). Epidemiology of fecal mutagenicity. Epidemiologic Reviews 8, 92-105.

Schiffman, M. H. (1987). Diet and faecal genotoxicity. Cancer Surveys 6, 653-672.

Schiffman. M. H., Tasscll, R. V., Robinson, A., Smith, L. \& Daniel, J. (1988). Current research on fecal mutagenicity. American Journal of Epidemiology 127, 415-416.

Segal, I., Walker, A. R. P., Lord, S. \& Cummings, J. H. (1988). Breath methane and large bowel cancer risk in contrasting African populations. Gut 29, 608-613.

Setchell, K. D. R., Street, J. M. \& Sjovall, J. (1987). Faecal bile acids. In The Bile Acids, pp. 441-571 [K. D. R. Setchell, D. Kritchevsky and P. P. Nair, editors]. New York: Plenum.

Sjodin, P. B., Nyman, M. E., Nilsson, L., Asp, N. G. \& Jagerstad, M. I. (1985). Binding of ${ }^{14} \mathrm{C}$ labelled food mutagens by dietary fibre in vivo. Journal of Food Sciences 50, 1-5.

Slattery, M. L., Schumacher, M. C., Smith, K. R., West, D. W. \& Abd-Elghany, N. (1988). Physical activity, diet and risk of colon cancer in Utah. American Journal of Epidemiology 128, 989-999.

Smith, A. H. . Pearce, N. E. \& Joseph, J. G. (1985). Major colorectal cancer. Aetiological hypotheses do not explain mortality trends among Maori and non-Maori New Zealanders. International Journal of Epidemiology 14, 79-95.

Smith, P. J. (1986). n-Butyrate alters chromatin accessibility to DNA repair enzymes. Carcinogenesis 7 , $423-429$.

Solomon, E., Voss, R., Hall, V., Bodmer, W. F., Jass, J. R., Jeffries, H. A., Lucibello, F. C., Patel, I. \& Rider, S. H. (1987). Chromosome 5-allele loss in human colorectal carcinomas. Nature 328, 616-619.

Stampfer, M. J., Willett, W. C., Colditz, G. A., Rosner, B., Hennekens, C. \& Speizer, F. E. (1987). Prospective study of diet and cancer in a cohort of women. Federation Proceedings 46, 883A.

Stephen, A. M. \& Cummings, J. H. (1980). Mechanism of action of dietary fibre in the human colon. Nature 284, 283-284.

Sugimura, T. (1985). Carcinogenicity of mutagenic heterocyclic amines. Mutagen Research 150, 33-41.

Takano, S., Matshushima, M., Erturk, E. \& Bryan, G. T. (1981). Early reduction of rat colonic epithelial ornithine and S-adenosyl methionine decarboxylase activities by MNNG or bile salts. Cancer Research $\mathbf{4 1}$, 624-628.

Thornton, J. R. (1981). High colonic pH promotes colorectal cancer. Lancet i, 1081-1083. 
Trowell, H. (1985). Dietary fibre: a paradigm. In Dietary Fibre, Fibre-depleted Foods and Disease, p. 3 [H. Trowell, D. Burkitt and K. Heaton, editors]. Florida, USA: Academic Press.

Tuyns, A. J., Haelterman, M. \& Kaaks, R. (1987). Colorectal cancer and the intakes of nutrients: a case control study in Belgium. Nutrition and Cancer 10, 181-186.

Tuyns, A. J.. Kaaks, R. \& Haelterman, M. (1988). Colorectal cancer and the consumption of foods; a case control study in Belgium. Nutrition and Cancer 11, 189-204.

Varo, P., Laine, R., Veijalainen, K., Pcro, K., Wetterhof, A. \& Koivistoinen, P. (1984). Dietary fibre and available carbohydrates in Finnish cercal products, vegetables and fruits. Journal of Agricultural Science, Finland 56, 39-59.

Venitt, S. (1988). Mutagens in human facces and cancer of the large bowel. In Role of the Gut Flora in Toxicity and Cancer, pp. 399-460 [I. R. Rowland, editor]. London: Academic Press.

Venitt, S., Bosworth, D. \& Aldrick, A. J. (1986). Pilot study of the effect of diet on the mutagenicity of human faeces. Mutagenesis 1, 353-358.

Vernia, P., Ciarniello, P., Cittadini, M., Lorenzotti, A., Alessindrini, A. \& Caprilli, R. (1988). Stool pH and SCFA in colorectal cancer and polyps. Gastroenterology 96, A528.

Virtanen, S. M. \& Varo, P. (1988). Dietary fibre and fibre fractions in the diet of Finnish diabetic and non-diabetic adolescents. European Journal of Clinical Nutrition 42, 169-175.

Visek, W. J. (1978). Diet and cell growth by ammonia. American Journal of Clinical Nutrition 31, S216-S220.

Walker, A. R. P., Walker, B. F. \& Walker, A. J. (1986). Faecal pH, dietary fibre intake and proneness to colon cancer in four South African populations. British Journal of Cancer $\mathbf{5 3}, 489-495$.

Ward, J. M., Anjo, T., Ohannesian, L., Keafer, L. K., Devor, D. E., Donovan, P. J., Smith, G. T., Henneman, J. R., Streeter, A. J., Konishi, N., Rehm, S., Reist, E. J., Bradford, W. W. \& Rice, J. M. (1988). Inactivity of fecapentaene-12 as a rodent carcinogen or tumor initiator. Cancer Letters 42, 49-59.

Wattenberg, L. W. (1990). Inhibition of carcinogenesis by minor anutrient constituents of the diet. Proceedings of the Nutrition Society 49, 173-183.

Whitehead, R. H., Young, G. P. \& Bhathal, P. S. (1986). Effects of SCFA on a new human colon carcinoma cell line (LIM 1215). Gut 27, 1457-1463.

Wolpert, E., Phillips, S. F. \& Summerskill, W. H. J. (1971). Transport of urea and ammonia production in the human colon. Lancet ii, 1387-1390.

Wrong, O. M., Vince, A. J. \& Waterlow, J. C. (1985). The contribution of endogenous urea to faecal ammonia in man. Clinical Science 68, 193-199.

Wynder, E. L., Kajitani, T., Ishikawa, S., Dodd, H. \& Takano, A. (1969). Environmental factors of cancer of the colon and rectum. Cancer 23, 1210-1220.

Young, T. B. \& Wolf, D. B. (1988). Case control study of proximal and distal colon cancer and diet in Wisconsin. International Journal of Cancer 42, 167-175. 